\title{
MODEL SPASIAL TEMPORAL DAMPAK KENAIKAN MUKA AIR LAUT TERHADAP PERMUKIMAN PENDUDUK DI PULAU KECIL (KASUS: PULAU KARIMUNJAWA DAN PULAU KEMUJAN, KABUPATEN JEPARA)
}

\author{
Ati Rahadiati1) \\ Ernik Yuliana2) \\ Rani Hafsaridewi3) \\ Benny Khairuddin $\left.{ }^{3}\right)$ \\ Luh Putu Ayu Savitri Citra Kusuma3) \\ Robet Perangin Angin ${ }^{3)}$ \\ Hasan Eldin Adimu4) \\ Jotham S.R. Ninef5) \\ Muliani Galib6) \\ Sudirman Adibrata $\left.{ }^{7}\right)$ \\ 1) Badan Informasi Geospasial \\ 2) FMIPA Universitas Terbuka \\ 3) Kementerian Kelautan dan Perikanan \\ 4) Universitas Halu Oleo \\ 5) Universitas Nusa Cendana \\ 6) Kementerian Lingkungan Hidup dan Kehutanan \\ 7) Universitas Bangka Belitung \\ e-mail: arahadiati@gmail.com
}

\begin{abstract}
Coastal areas (especially small islands) are vulnerable to impact from sea level rise (SLR). The submergence of areas that are economic centers will impactin huge losses. To avoid such losses it is necessary to manage small islands by using temporal spatial models. The aim of this article is to describe the development of a temporal spatial model to assess the vulnerability of settlements in small islands. The method used is dynamic system modeling combined with Geographic Information System (GIS) based on identification of environmental issues and conditions in small island, in this case Karimunjawa Island and Kemujan Island, Jepara Regency. The assumption used in the modeling is that there is no natural disaster or calamity that reduces the population, the death is considered normal death by referring to the average life expectancy of the Indonesian population (69 years), no coastal reclamation activities, no significant changes in ecosystem. The modeling results indicate that if the fraction of SLR $10 \mathrm{~cm}$ per year, will have an impact on the decreasing availability of settlement land. The height of $S L R$ ranges from 0,5 meters in the $10^{\text {th }}$ year, to 5,0 meters in the $100^{\text {th }}$ year. As a result there will be puddle in the residential area of 13,02 ha in the $10^{\text {th }}$ year and in the $100^{\text {th }}$ year to 226,5 ha. Required environmental engineering efforts, such as develop coastal dike and reform plan of building, to reduce impact on the availability of settlement land. SLR that is affecting populations and settlements on Karimunjawa and Kemujan Island, require adaptation as an impact mitigation effort.
\end{abstract}


Keywords: Karimunjawa, Kemujan, model, small island, spatial

\begin{abstract}
ABSTRAK
Wilayah pesisir (terutama pulau kecil) sangat rentan terkena dampak dari peningkatan muka air laut. Terendamnya wilayah-wilayah yang merupakan sentra ekonomi akan mengakibatkan kerugian yang sangat besar. Untuk menghindari kerugian tersebut perlu pengelolaan pulau-pulau kecil dengan memanfaatkan model spasial dinamik/temporal. Tujuan studi adalah mengembangkan model spasial dinamik/temporal untuk mengkaji kerentanan permukiman penduduk di pulau-pulau kecil. Metode yang digunakan adalah pemodelan sistem dinamik/temporal (SD) dipadukan dengan Sistem Informasi Geografis (SIG) berdasarkan identifikasi isu dan kondisi lingkungan di pulau kecil, yaitu Pulau Karimunjawa dan Pulau Kemujan, Kabupaten Jepara. Data yang digunakan adalah data pertumbuhan penduduk (data sekunder) dan peta dasar Pulau Karimunjawa dan Kemujan. Asumsi yang digunakan pada pemodelan adalah tidak terjadi bencana alam atau musibah yang mengurangi jumlah penduduk, kematian dianggap sebagai kematian normal dengan mengacu umur rata-rata harapan hidup penduduk Indonesia (69 tahun), tidak ada kegiatan reklamasi pantai, tidak ada perubahan ekosistem secara signifikan. Pemodelan spasial dinamik/temporal mengikuti tahapan sesuai dengan prosedur pemodelan. Hasil pemodelan menunjukkan bahwa bila fraksi sea level rise (SLR) $10 \mathrm{~cm}$ per tahun, akan berdampak pada penurunan ketersediaan lahan permukiman. Tinggi kenaikan muka air laut berkisar antara 0,5 meter pada tahun ke-10, hingga mencapai ketinggian kenaikan 5,0 meter pada tahun ke-100. Akibatnya akan terjadi genangan air laut di permukiman penduduk seluas 13,02 ha pada tahun ke-10 danpada tahun ke-100 menjadi 226,5 ha. Diperlukan upaya rekayasa lingkungan, seperti membangun tanggul pantai dan memperbaiki rancangan konstruksi bangunan permukiman, agar dapat mengurangi dampak terhadap ketersediaan lahan permukiman. Kenaikan muka air laut yang berdampak terhadap penduduk dan permukiman di Pulau Karimunjawa dan Kemujan membutuhkan adanya adaptasi sebagai upaya mitigasi dampak.
\end{abstract}

Kata kunci: model, pulau kecil, Karimunjawa, Kemujan, spasial

Wilayah pesisir dan pulau-pulau kecil dapat dimanfaatkan untuk perencanaan dan pengelolaan sumberdaya hayati laut seperti pengembangan potensi perikanan dan sarana pendukungnya yang sangat potensial bagi perkembangan perekonomian masyarakat. Wilayah pesisir sangat rentan terkena dampak dari peningkatan muka air laut. Penyebab kenaikan muka air laut adalah mencairnya es di kutub, kejadian iklim ekstrim (global warming), dan turunnya permukaan tanah. Terendamnya wilayah-wilayah yang merupakan sentra ekonomi akan mengakibatkan kerugian yang sangat besar, namun akan berbeda untuk setiap penggunaan lahan. Besarnya nilai kerugian ekonomi akan bergantung pada tingkat produktivitas lahan yang tergenang; misalnya pada ekosistem yang rentan seperti wilayah mangrove, kenaikan muka air laut akan mengubah zonasi vegetasi semula. Contoh lain, terjadinya kenaikan muka air laut di kawasan permukiman masyarakat di pesisir akan menimbulkan masalah pengungsi, timbulnya wabah penyakit dan menurunnya kualitas air tanah. Adaptasi dan mitigasi akibat adanya perubahan pada lingkungan pesisir akan sangat membantu mengurangi kerugian sehingga menjadi penting untuk memprediksi kenaikan muka air laut beberapa tahun ke depan. 
Upaya adaptasi terhadap kenaikan muka air laut menurut Diposaptono, Budiman, \& Agung (2009) dapat dilakukan dengan dua hal, yaitu upaya fisik dan non fisik. Upaya fisik dapat berupa perlindungan alami dan buatan. Sementara upaya nonfisik dapat dilakukan dengan membuat peta rawan bencana, informasi publik dan penyuluhan, pelatihan serta simulasi mitigasi bencana. Upaya fisik merupakan upaya perlindungan dengan membangun infrastruktur untuk melindungi wilayah dari kenaikan muka laut, baik itu banjir rob maupun pasang surut air laut. Upaya fisik dengan metoda perlindungan alami dapat dilakukan dengan membuat penebalan wilayah mangrove, terumbu karang, atau hutan, sedangkan metoda buatan dapat dilakukan dengan membangun pemecah arus, tembok laut, tanggul, konstruksi perlindungan dan rumah panggung. Upaya nonfisik yang dilakukan pemerintah berupa tiga hal, yaitu: 1) pembuatan peta rawan bencana, peta ini digunakan untuk mengetahui wilayah-wilayah yang rentan terhadap bencana kenaikan muka air laut. Peta ini juga dijadikan sebagai acuan untuk mementukan tempat relokasi dan juga penentuan tata ruang dan tata guna lahan pesisir. Selain itu, peta juga digunakan sebagai zonasi penetapan sempadan pantai dan sungai; 2) penetapan sempadan pantai dan sungai, dimana pemerintah harus melakukan penyuluhan dan penyampaian informasi ke publik; 3) pemerintah mengadakan pelatihan dan simulasi mitigasi bencana (Diposaptono et al., 2009).

Menurut kajian Overseas Development Institute \& Climate \& Development Knowledge Network (2014), dampak perubahan iklim yang dihasilkan dari studi Intergovernmental Panel on Climate Change (IPCC) memberikan pesan mengenai adaptasi dan mitigasi terhadap perubahan iklim bagi negara-negara kepulauan yang sedang berkembang (Small Island Developing States, SIDS). Hal tersebut relevan dengan pulau-pulau kecil yang ada di Indonesia. Pulau kecil menurut UU No. 27 Tahun 2007 tentang Pengelolaan Wilayah pesisir dan Pulau-Pulau Kecil adalah pulau dengan luas $\leq 2.000 \mathrm{~km}^{2}$ beserta kesatuan ekosistemnya. Adaptasi dan mitigasi terhadap perubahan iklim tersebut, diantaranya adalah sebagai berikut (Overseas Development Institute \& Climate \& Development Knowledge Network, 2014):

1. Iklim telah berubah dan pulau-pulau kecil telah merasakan dampaknya.

2. Perubahan iklim tidak dapat terhindarkan dalam dekade-dekade mendatang.

3. Perubahan iklim mempengaruhi pertumbuhan dan pembangunan pulau-pulau kecil.

4. Adaptasi dapat mengurangi dampak perubahan iklim, tetapi terdapat batasan dan resiko di dalamnya.

5. Biaya ekonomi adaptasi terhadap perubahan iklim pada pulau-pulau kecil relatif tinggi terhadap kemampuan ekonominya.

Banyak pulau kecil yang memiliki keterbatasan infrastruktur, sumberdaya alam, manusia, dan ekonomi, dan umumnya penduduk pulau kecil tergantung pada sumberdaya pesisir dan laut untuk memenuhi kebutuhan proteinnya. Sebagian besar perekonomian penduduk pulau-pulau kecil tergantung pada sumberdaya yang terbatas dan tergantung pada berbagai faktor luar. Pulau-pulau kecil umumnya memiliki kemampuan adaptasi yang rendah, dan kebutuhan biaya adaptasi yang relatif tinggi, meskipun secara tradisional ada beberapa resiliensipada pulau-pulau kecil dalam menghadapi perubahan lingkungan (Mimura et al., 2007).

Permukiman dan aktivitas sosial ekonomi penduduk yang terkonsentrasi di/dekat pantai sering dijumpai di pulau-pulau kecil. Desa nelayan, bangunan pemerintah dan fasilitas penting seperti rumah sakit seringkali terletak di dekat pantai. Lebih jauh, pertumbuhan penduduk dan migrasi menambah tekanan terhadap permukiman, fasilitas umum, dan sumberdaya di pesisir, serta menimbulkan persoalan seperti pencemaran, pembuangan limbah dan kebutuhan permukiman. Perubahan muka air laut dan frekuensi badai dapat memiliki konsekuensi serius terhadap 
permukiman penduduk. Pada sisi lain, permukiman dan peduduk di bagian dalam pulau dapat sangat dipengaruhi oleh dampak negatif dari aktivitas pertanian, karena umumnya mereka tergantung pada produksi tanaman pangan untuk kebutuhan pangannya (Mimura et al., 2007). Oleh karena itu permukiman dan aktivitas sosial ekonomi di pulau kecil sangatlah rentan, sehingga diperlukan upaya pencegahan kerusakan. Salah satu upaya tersebut adalah dengan pemodelan spasial temporal yang menghasilkan model prediksi pada beberapa tahun yang akan datang, sehingga dapat disiapkan skenario-skenario kebijakan yang diperlukan. Pemodelan spasial temporal merupakan kombinasi antara sistem dinamik dan Sistem Informasi Geografis (SIG). Kelebihan dari kombinasi dua pendekatan ini adalah dapat menggambarkan perubahan dalam waktu dan ruang secara dinamik. Pemodelan spasial temporal dapat membantu dalam mendapatkan skenario terbaik berdasarkan dampak yang dihasilkan proses simulasi skenario (Anonim, 2013). Salah satu contoh penerapan pemodelan spasial temporal adalah penelitian yang dilakukan oleh Sahin \& Mohamed (2010) untuk memprediksi pengaruh kenaikan muka air laut di daerah pesisir.

Pulau Karimunjawa dan Kemujan merupakan pulau kecil yang berada di Kecamatan Karimunjawa, Kabupaten Jepara. Saat ini terdapat 4 desa yang berada di Kecamatan Karimunjawa, yaitu Desa Karimunjawa, Kemujan, Parang, dan Nyamuk yang diresmikan pada bulan Agustus 2011. Berdasarkan data stastistik, jumlah penduduk di Kecamatan Karimunjawa mencapai 9.242 dengan laju pertumbuhan 0,36 \% per tahun pada tahun 2015 (BPS, 2016). Pulau Karimunjawa dan Kemujan yang mempunyai luas 3.188 ha mengalami perkembangan yang cukup pesat. Hal ini terjadi terutama ketika sektor pariwisata digalakkan. Jumlah wisatawan yang datang memicu pertumbuhan hotel dan penginapan. Banyak lahan yang beralih fungsi, terutama lahan mangrove dan perbukitan. Terdapat beberapa lokasi mangrove yang beralih fungsi menjadi lahan permukiman, baik untuk kebutuhan rumah penduduk maupun untuk hotel dan penginapan (Hafsaridewi et al., 2018). Oleh karena itu, studi tentang pemodelan kenaikan permukaan air laut perlu dilakukan, agar dapat diprediksi pengaruhnya terhadap permukiman.

Tujuan studi ini adalah: 1) mengembangkan model spasial dinamik/temporal untuk mengkaji kerentanan permukiman penduduk di pulau-pulau kecil pada saat ini dan di masa depan terhadap kenaikan muka air laut berdasarkan beberapa skenario dan proyeksi kenaikan muka air laut; 2) memprediksi dampak kenaikan muka air laut terhadap permukiman penduduk.

\section{METODE}

Metode yang digunakan pada kajian ini adalah pemodelan system dynamics (SD) yang dipadukan dengan Sistem Informasi Geografis (SIG). Untuk memodelkan dan mensimulasikan perubahan di wilayah pulau-pulau kecil, perlu dipertimbangkan dimensi spasial dan temporal dari kenaikan muka air laut. Model dinamik digunakan untuk mensimulasikan seberapa besar perubahanperubahan muka air laut dan dampaknya terhadap permukiman penduduk di Pulau Karimunjawa dan Pulau Kemujan. SIG memiliki struktur pengelolaan basis data yang kuat, sehingga memberikan antarmuka user-friendly dan interaktif, namun hanya didesain untuk komponen spasial. Pendekatan terpadu dengan menggabungkan SIG dan SD dapat menjawab permasalahan yang kompleks terkait kenaikan muka air laut di wilayah pesisir. Penggabungan SIG dan SD menjadi cara yang memungkinkan proses-proses di wilayah pesisir dapat dipahami secara ruang (spasial) dan waktu (temporal), dan dapat secara efektif menjawab isu-isu lingkungan, karena penggabungan tersebut mampu memprediksi kondisi yang terjadi di masa yang akan datang. Model spasial-temporal mampu menggambarkan perubahan pada sistem pulau-pulau kecil berdasarkan waktu, sekaligus menelusuri sebaran perubahan tersebut secara spasial, yang pada gilirannya dapat digunakan untuk memahami 
dinamika proses-proses lingkungan. Memodelkan proses-proses yang terjadi di pulau-pulau kecil (proses ekologi, sosial, dan ekonomi) dapat menjadi alat penting dalam memperoleh informasi kuantitatif untuk perencanaan dan pengelolaan wilayah pesisir (Sahin, 2011). Model yang dihasilkan dapat dijadikan dasar kebijakan karena berisi skenario-skenario berdasarkan situasi yang terjadi saat ini dan sebelumnya.

\section{Model Dinamik/Temporal}

Sebuah model adalah suatu bentuk yang dibuat untuk menirukan suatu gejala atau proses. Model dapat dikelompokkan menjadi model kuantitatif, kualitatif, dan ikonik (Muhammadi, Aminullah, Soesilo 2001). Model kuantitatif merupakan model yang berbentuk rumus-rumus matematika, statistika, atau komputer. Model dinamik merupakan model kuantitatif yang berbentuk model komputer. Ada perbedaan filosofi antara model matematika dan model dinamik. Model dinamik menekankan perubahan dari waktu ke waktu dan menvisualisasikan setiap komponen model dan hubungan antar setiap komponen tersebut. Lain halnya dengan model matematika yang berusaha untuk mengembangkan persamaan ringkasan yang akan menghitung jawaban untuk satu set input tertentu (Dudley, 2008). Pengembangan model dilakukan dengan prinsip-prinsip pada Gambar 1. Dari gejala proses yang ada di alam kemudian diterjemahkan dengan menyusun konsep terlebih dulu, lalu pengembangan model, simulasi, dan validasi model.

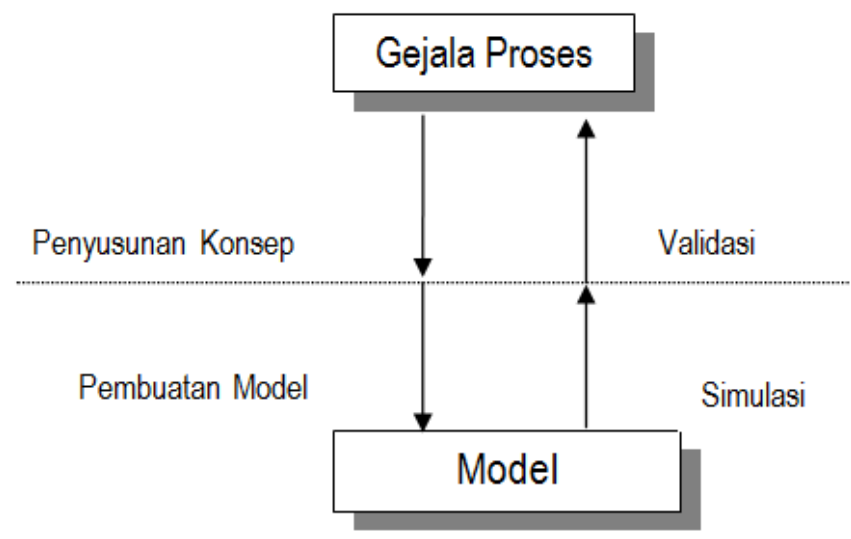

Gambar 1. Kerangka dasar pemodelan dinamik/temporal (Muhammadi,et al., 2001)

Dalam kajian ini model yang dibangun adalah model dinamik kenaikan muka air laut terhadap lahan permukiman di Pulau Karimunjawa dan Pulau Kemujan. Untuk membangun model ini tahapan yang dilakukan berdasarkan kerangka dasar pada Gambar 1 adalah sebagai berikut:

1. Penyusunan konsep, dilakukan untuk memahami gejala dunia nyata yang ingin ditirukan.

Keluaran dari penyusunan konsep adalah causal loop diagram (CLD). Pada kajian ini dihasilkan tiga submodel yang terdiri atas submodel penduduk, submodel permukiman, dan submodel sea level rise.

2. Pembuatan model. CLD yang dihasilkan kemudian diterjemahkan ke dalam bahasa komputer dan menghasilkan stock flow diagram (SFD). Perangkat lunak yang digunakan pada kajian ini adalah Powersim. 
3. Input data dan simulasi model. Data yang telah dikumpulkan kemudian diinput kedalam SFD yang telah dibangun, sehingga dapat dilakukan simulasi yang akan menghasilkan tabel data dan grafik.

4. Melakukan validasi model. Validasi dilakukan untuk mengetahui kesesuaian antara hasil simulasi dengan gejala atau proses yang ditirukan. Validasi dilakukan dengan dua tahap, yang pertama validasi perilaku yaitu membandingkan perilaku grafik data referensi yang akan ditiru dan perilaku grafik hasil simulasi model. Tahap selanjutnya dihitung perbedaannya dengan menggunakan nilai avarage mean error (AME). Jika nilai AME ini kurang dari $10 \%$ (Muhammadi,et al, 2001), maka dapat dikatakan model ini valid. Rumus yang digunakan adalah:

$$
A M E=\frac{S i-A i}{A i} \times 100 \%
$$

Keterangan:

$\mathrm{Si}=$ Rata-rata data hasil Simulasi

$\mathrm{Ai}=$ Rata-rata data referensi atau aktual

\section{Sistem Informasi Geografis (SIG)}

SIG dapat dimanfaatkan untuk mempermudah dalam mendapatkan berbagai data yang telah diolah dan tersimpan sebagai atribut suatu lokasi atau objek. Data yang diolah dalam SIG pada dasarnya terdiri atas data spasial dan data atribut dalam bentuk digital. Contohnya adalah data sebaran/jumlah penduduk (atribut) di suatu kabupaten (data spasial). Sistem ini merelasikan data spasial (contoh: lokasi kabupaten) dengan data nonspasial (jumlah penduduk), sehingga para penggunanya dapat membuat peta beserta atributnya, dan menganalisis informasi yang dihasilkan sesuai dengan tujuan analisisnya. SIG juga memelihara data dalam bentuk digital sehingga data dalam SIG lebih padat dibandingkan dengan data dalam bentuk peta cetak, tabel, atau bentuk konvensional lainya, sehingga data dalam SIG akan mempercepat pekerjaan dan meringankan biaya yang diperlukan.

Saat ini, SIG sering dipadukan dengan Model Dinamis/Temporal untuk mendapatkan informasi yang lebih maksimal. Pertimbangannya adalah kondisi lingkungan yang selalu dinamis karena pengaruh iklim, cuaca, waktu, dan faktor lainnya. Faktor-faktor kedinasmisan tersebut diperlukan dalam SIG dan SD agar penggunanya dapat menganalisis keduanya (spasial dan temporal) untuk keperluan penentuan kebijakan di masa mendatang. Konsep perencanaan spasial dinamis disajikan pada Gambar 2.

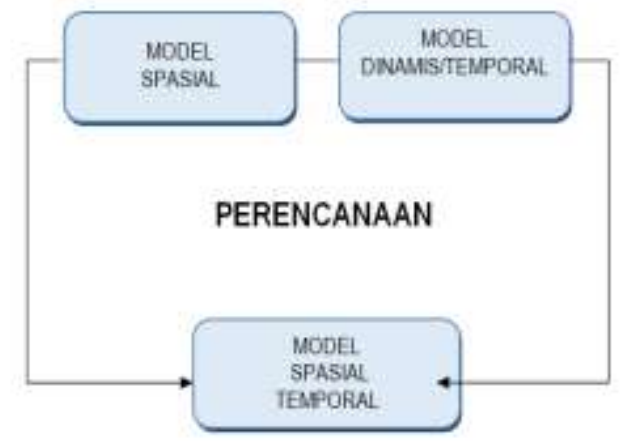

Gambar 2. Konsep perencanaan spasial dinamis 


\section{HASIL DAN PEMBAHASAN}

Model yang dibangun bertujuan untuk memprediksi dampak kenaikan muka air laut terhadap ketersediaan lahan pemukiman dan pertumbuhan penduduk. Dalam model ini tersusun tiga submodel, yaitu subsistem: 1) kenaikan muka air laut/sea level rise (SLR); 2) ketersediaan lahan pemukiman; dan 3) pertumbuhan penduduk. Asumsi yang digunakan pada model ini adalah tidak terjadi bencana alam atau musibah yang mengurangi jumlah penduduk, kematian dianggap sebagai kematian normal dengan mengacu umur rata-rata harapan hidup penduduk Indonesia (69 tahun), tidak ada kegiatan reklamasi pantai, dan tidak ada perubahan ekosistem secara signifikan. Submodel pertumbuhan penduduk dipengaruhi oleh tingkat kelahiran, kematian, dan migrasi. Semakin meningkat jumlah penduduk, maka kebutuhan lahan permukiman akan meningkat. Sementara lahan permukiman dipengaruhi oleh adanya SLR. Pemahaman konsep ini kemudian diterjemahkan ke dalam bahasa komputer. Diagram alir (SFD) dapat dilihat pada Gambar 3. Kemudian dengan menggunakan SFD tersebut dilakukan simulasi model untuk mendapatkan grafik sehingga dapat dilakukan prediksi kenaikan muka air laut.

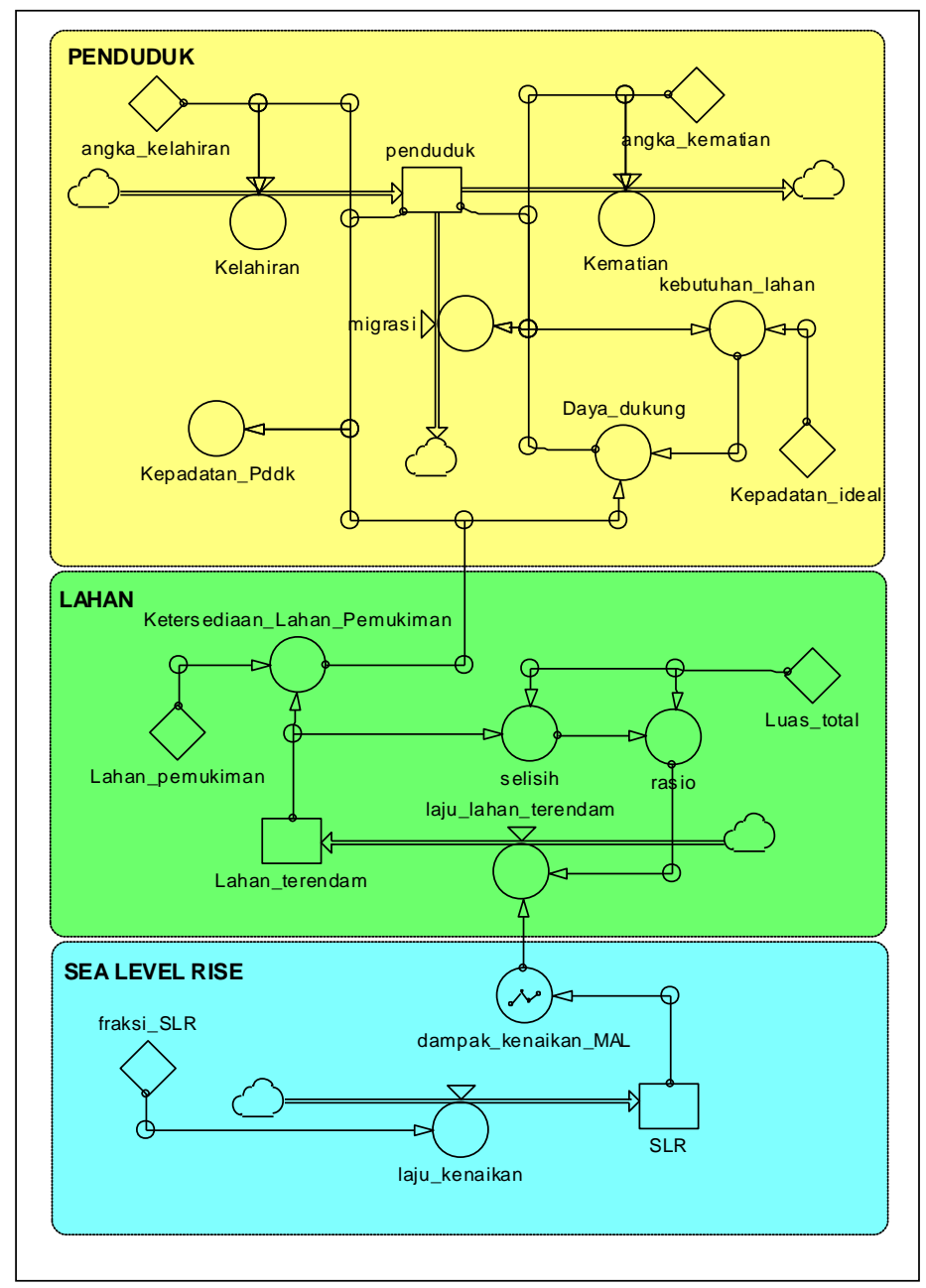

Gambar 3. Diagram alir model dampak kenaikan muka air laut terhadap ketersediaan lahan pemukiman dan pertumbuhan penduduk 
Pada subsistem SLR, bila fraksi SLR adalah $10 \mathrm{~cm}$ per tahun, maka akan berdampak pada penurunan ketersediaan lahan permukiman dalam luasan tertentu. Besaran luasan tersebut yang menjadi output dari model dinamik/temporal, dan lokasi terjadinya penurunan ketersediaan lahan menjadi output model spasial. Dengan demikian, dapat ditentukan upaya rekayasa lingkungan agar dapat mengurangi dampak terhadap ketersediaan lahan pemukiman di suatu lokasi. Berdasarkan hasil simulasi model ketersediaan lahan pemukiman akibat dampak kenaikan muka air laut sebesar $10 \mathrm{~cm} /$ tahun dapat dilihat pada Gambar 4.

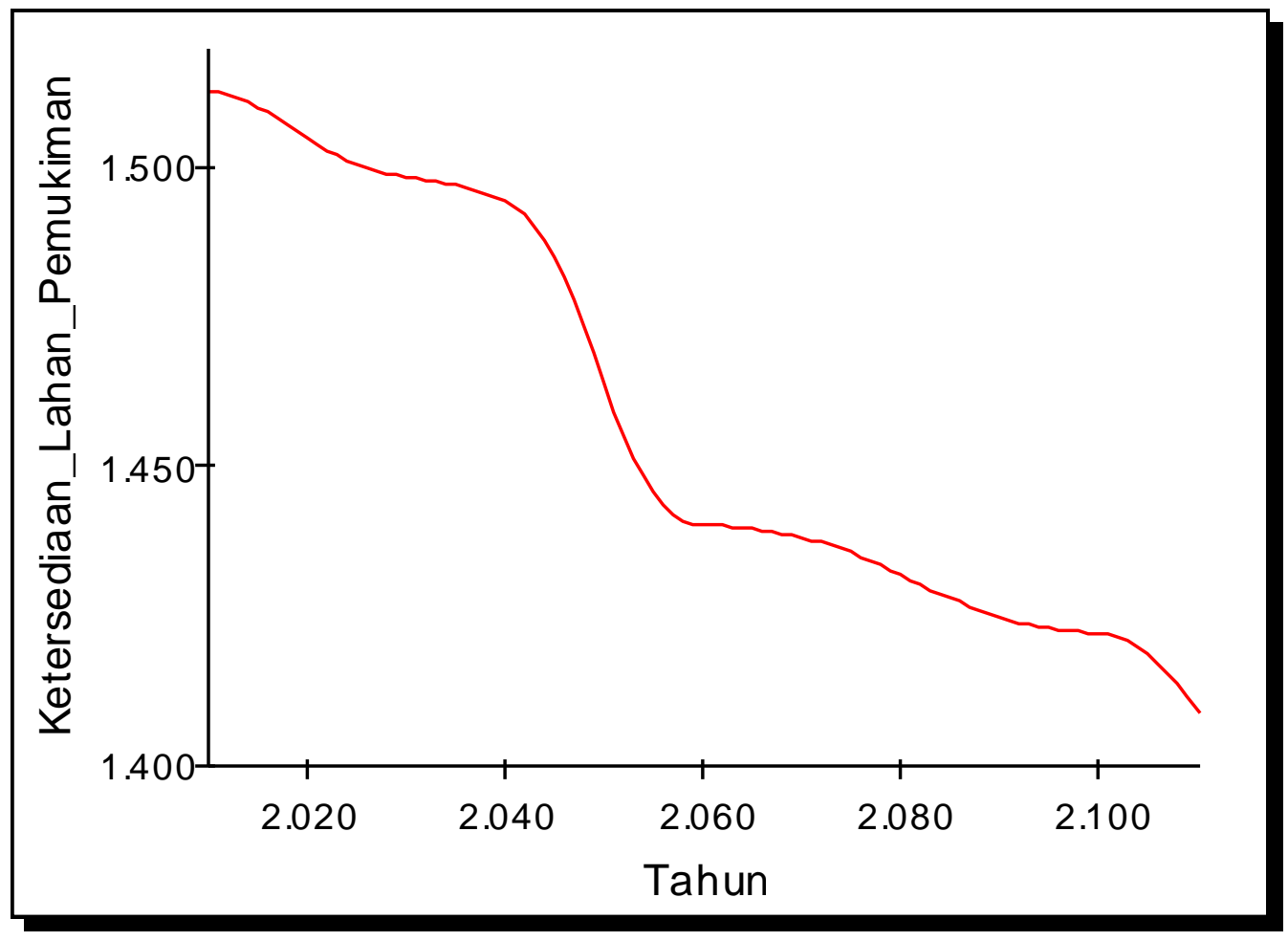

Gambar 4. Dampak kenaikan muka air laut terhadap ketersediaan lahan pemukiman (Ket: grafik adalah output dan pemodelan dinamik/temporal jika terjadi SLR $10 \mathrm{~cm}$ )

Ketersediaan lahan permukiman akan mempengaruhi daya dukung pulau untuk menampung penduduknya. Daya dukung ini akan mempengaruhi tingkat migrasi, dimana jika kondisi lingkungan yang tidak nyaman akan menyebabkan penduduk berpindah ke tempat yang lain. Berdasarkan hasil simulasi selama 100 tahun, dapat terlihat bahwa pertumbuhan penduduk akan semakin lambat yang akhirnya akan stagnan, sehingga dalam simulasi akan menghasilkan perilaku model yang goalseeking (pencapaian tujuan, muncul dari umpan balik yang negatif). Hal tersebut menunjukkan bahwa daya dukung pulau kecil sudah mulai menurun karena terbatasnya lahan permukiman. Pertumbuhan seperti ini disebabkan oleh adanya keterbatasan daya dukung pulau dalam menampung jumlah penduduk. Dampak kenaikan muka air laut terhadap pertumbuhan penduduk dapat dilihat pada Gambar 5. 


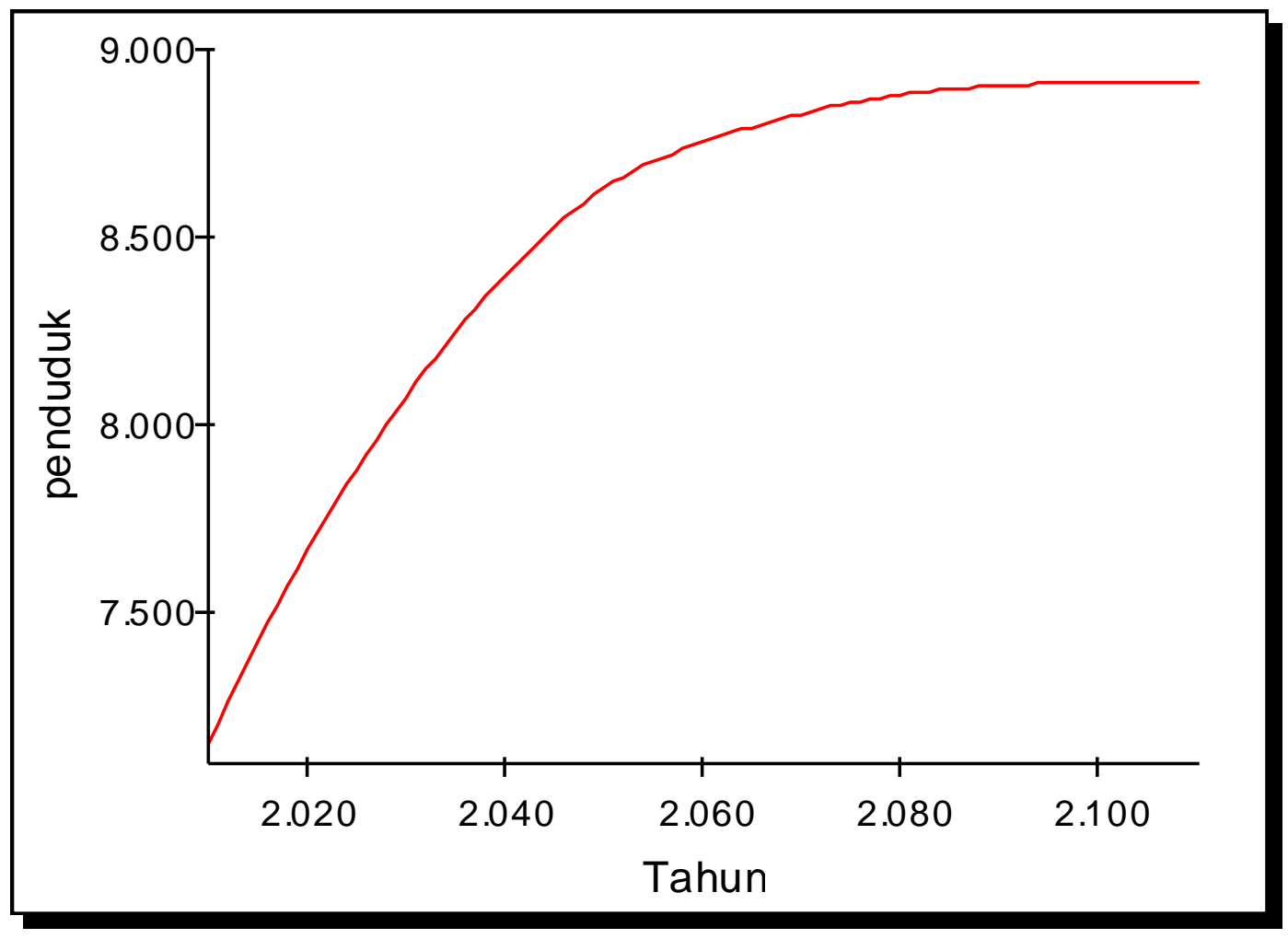

Gambar 5. Dampak kenaikan muka air laut terhadap pertumbuhan penduduk (Ket: grafik adalah output dan pemodelan dinamik/temporal jika terjadi SLR $10 \mathrm{~cm}$ )

Secara kuantitatif luas genangan pada lahan permukiman akibat SLR disajikan pada Tabel 1 dan 2, yang menunjukkan luas genangan pada lahan permukiman di Pulau Karimunjawa dan Kemujan akibat SLR pada berbagai level SLR selama kurun waktu hingga tahun ke-100. Genangan tersebut merupakan genangan permanen, yang berarti jika terjadi kenaikan muka air laut (SLR) dengan ketinggian tertentu maka batas genangan tersebut merupakan garis pantai baru dengan nilai ketinggian tertentu. Hal ini berarti bahwa dengan semakin tinggi kenaikan muka air laut, maka akan terjadi kehilangan lahan pemukiman secara permanen.

Berdasarkan hasil simulasi pemodelan, Tabel 1 menunjukkan data analisis kenaikan muka air laut pada setiap 10 tahun selama 100 tahun dengan skenario kenaikan muka air laut sebesar 5 $\mathrm{cm}(0,05 \mathrm{~m})$ per tahun. Tinggi kenaikan muka air laut berkisar antara 0,5 meter pada tahun ke-10 hingga mencapai ketinggian kenaikan 5,0 meter pada tahun ke-100. Skenario SLR mengakibatkan terjadinya genangan air laut di lahan permukiman penduduk di Pulau Karimunjawa dan Kemujan seluas 13,02 ha pada tahun ke-10 dan terus mengalami peningkatan seiring dengan meningkatnya kenaikan muka air laut. Pada tahun ke-100 simulasi, diprediksi luas genangan air laut menjadi 226,5 ha. Penurunan luas lahan permukiman tersebut adalah hal yang sangat serius di pulau kecil karena pengurangan luas yang signifikan akibat SLR. 
Tabel 1. Skenario Kenaikan Muka Air Laut $5 \mathrm{Cm}$ Per Tahun dan Luas Area Genangan Selama Kurun Waktu 100 Tahun di Pulau Karimunjawa dan Kemujan

\begin{tabular}{ccc}
\hline Tahun ke & Kenaikan muka air laut $(\mathrm{m})$ & Luas genangan $(\mathrm{ha})$ \\
\hline 10 & 0,5 & 13,02 \\
20 & 1,0 & 25,78 \\
30 & 1,5 & 41,62 \\
40 & 2,0 & 63,38 \\
50 & 2,5 & 82,09 \\
60 & 3,0 & 103,96 \\
70 & 3,5 & 130,06 \\
80 & 4,0 & 155,83 \\
90 & 4,5 & 188,69 \\
100 & 5,0 & 226,49 \\
\hline
\end{tabular}

Tabel 2. Skenario Kenaikan Muka Air Laut $10 \mathrm{Cm}$ Per Tahun dan Luas Area Genangan Selama Kurun Waktu 100 Tahun di Pulau Karimunjawa dan Kemujan (Hasil simulasi pemodelan dinamika/temporal)

\begin{tabular}{ccc}
\hline Tahun ke & Kenaikan muka air laut $(\mathrm{m})$ & Luas genangan $(\mathrm{ha})$ \\
\hline 10 & 1,0 & 25,69 \\
20 & 2,0 & 63,24 \\
30 & 3,0 & 103,73 \\
40 & 4,0 & 155,94 \\
50 & 5,0 & 227,54 \\
60 & 6,0 & 314,24 \\
70 & 7,0 & 390,57 \\
80 & 8,0 & 471,27 \\
90 & 9,0 & 550,82 \\
100 & 10,0 & 618,15 \\
\hline
\end{tabular}

Tabel 2 menunjukkan skenario kenaikan muka air laut (SLR) $10 \mathrm{~cm}(0,1 \mathrm{~m})$ per tahun dan luas area genangan selama kurun waktu 100 tahun di Pulau Karimunjawa dan Kemujan. Hasil analisis SLR pada setiap 10 tahun selama 100 tahun dengan skenario SLR sebesar $10 \mathrm{~cm}(0,1 \mathrm{~m})$ per tahun menunjukkan kisaran tinggi muka air laut 1,0 meter pada tahun ke-10 meningkat menjadi 10,0 meter pada tahun ke-100. Skenario SLR ini mengakibatkan terjadinya genangan air laut di lahan pemukiman penduduk di Pulau Karimunjawa dan Kemujan seluas 25,69 ha pada tahun ke-10 dan terus mengalami peningkatan seiring dengan meningkatnya kenaikan muka air laut hingga tahun ke100 , luas genangan air laut menjadi 618,15 ha.

Hasil prediksi genangan air laut pada areal pemukiman di Pulau Karimunjawa dan Kemujan disajikan pada Gambar 6. Gambar 6 (a) menunjukkan skenario kenaikan muka air laut sebesar $5 \mathrm{~cm}$ per tahun dan pada tahun ke-50 mencapai ketinggian sebesar 2,5 meter dengan prediksi luas area genangan 82,09 ha. Gambar 6 (b) menunjukkan skenario kenaikan muka air laut sebesar 10 $\mathrm{cm}$ per tahun, dimana pada tahun ke-50 mencapai ketinggian sebesar 5,0 meter dengan prediksi 
luas area genangan 227,54 ha. Gambar 6 (c) menunjukkan skenario kenaikan muka air sebesar 5 $\mathrm{cm}$ per tahun, pada tahun ke-100 mencapai ketinggian sebesar 5,0 meter dengan prediksi luas area pemukiman yang mengalami genangan seluas 226,49 ha. Gambar 6 (d) menunjukkan skenario kenaikan muka air laut $10 \mathrm{~cm}$ per tahun dan pada tahun ke-100 mecapai ketinggian mukaair laut 10,0 meter, dengan prediksi luas area pemukiman yang mengalami genangan seluas 618,15 ha.

Berdasarkan hasil prediksi genangan tersebut maka dapat diamati bahwa dengan adanya kenaikan muka air laut akan berdampak terhadap peningkatan luas areal pemukiman yang tergenangi air laut secara permanen. Hal ini mengakibatkan luas lahan untuk pemukiman semakin berkurang. Saat ini luas lahan pemukiman penduduk di Pulau Karimunjawa dan Kemujan 96,47 ha dan sebagian besar berada pada lahan dataran rendah di dekat pantai yang rentan terhadap dampak kenaikan muka air laut.

Hasil simulasi spasial dinamik/temporal menunjukkan bahwa dengan skenario kenaikan muka air laut sebesar $5 \mathrm{~cm}$ per tahun, maka pada tahun ke-50 simulasi, hampir sebagian besar ( \pm $90 \%$ ) lahan pemukiman yang berada di dataran rendah akan mengalami genangan. Dengan skenario kenaikan muka air laut sebesar $10 \mathrm{~cm}$ pertahun, maka pada tahun ke-30, semua lahan pemukiman di dataran rendah akan mengalami genangan. Luas lahan eksisting dan potensial untuk lahan pemukiman saat ini sekitar 1.516,48 ha. Peningkatan luas genangan air laut pada lahan pemukiman mengakibatkan berkurangnya luas lahan potensial untuk pemukiman penduduk. Pada tahun ke-50 simulasi, dengan skenario kenaikan muka air laut $5 \mathrm{~cm}$ per tahun, maka luas lahan untuk pemukiman akan berkurang sekitar $5,41 \%$ dan dengan skenario kenaikan muka air laut $10 \mathrm{~cm}$ per tahun, maka luas lahan untuk pemukiman akan berkurang sekitar $14,93 \%$.

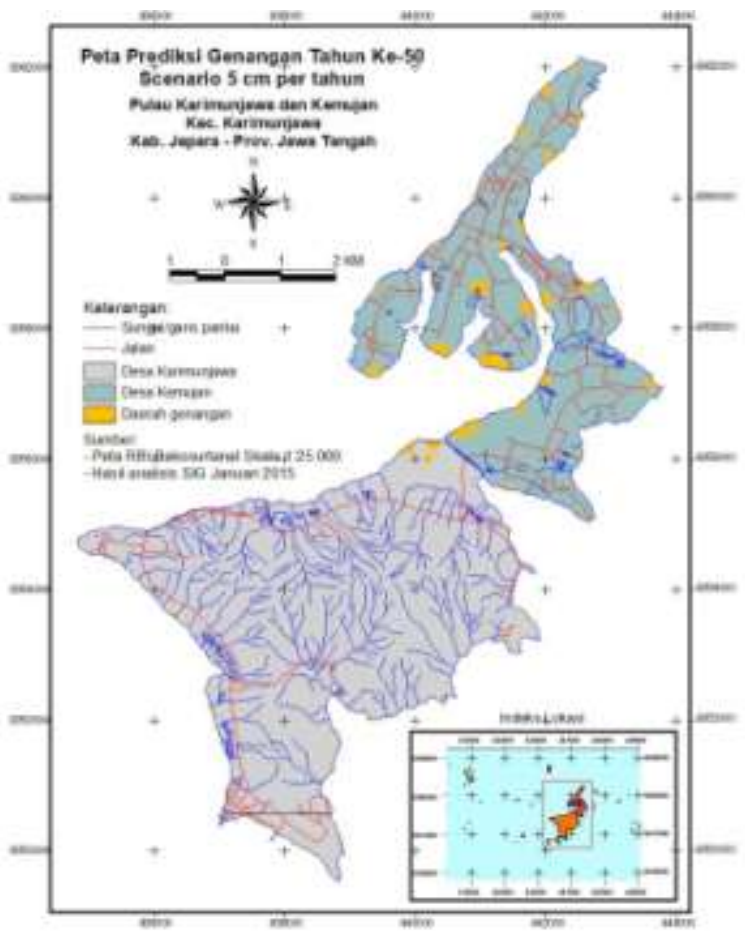

(a)

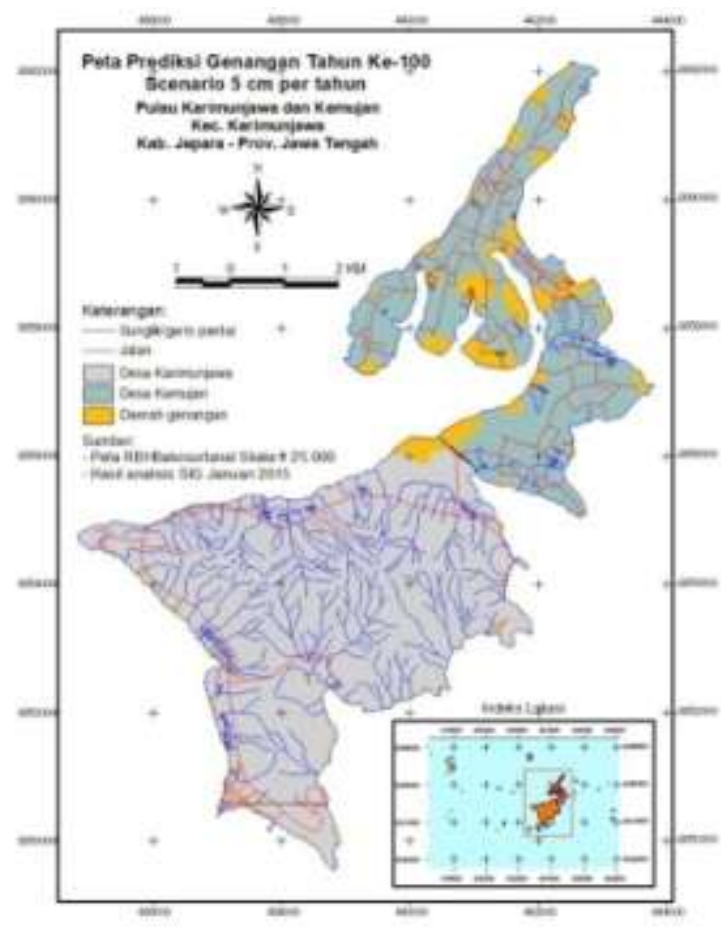

(b) 


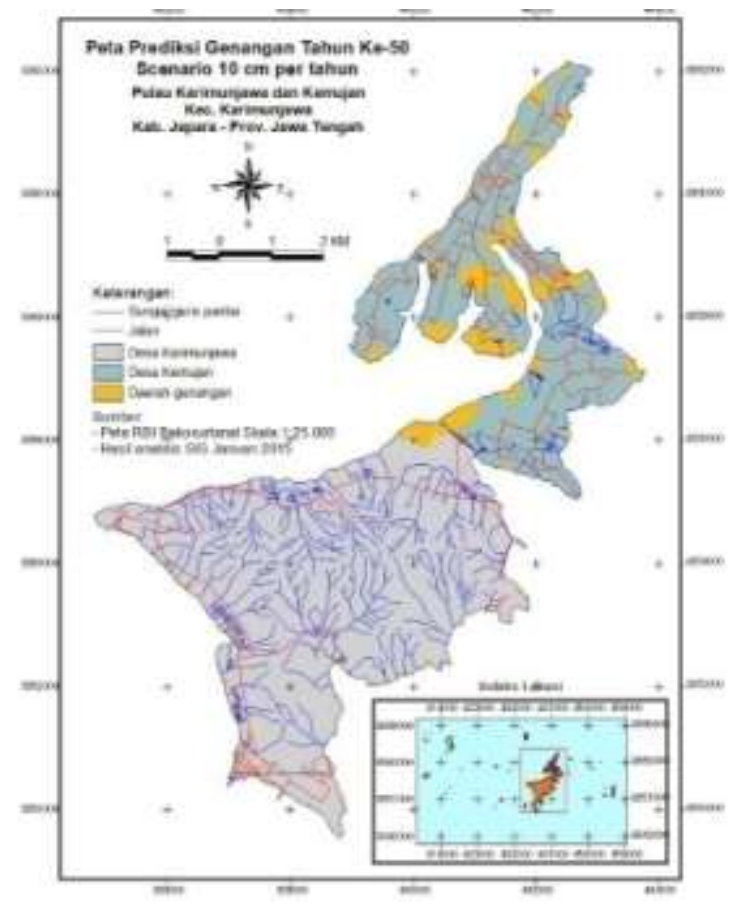

(c)

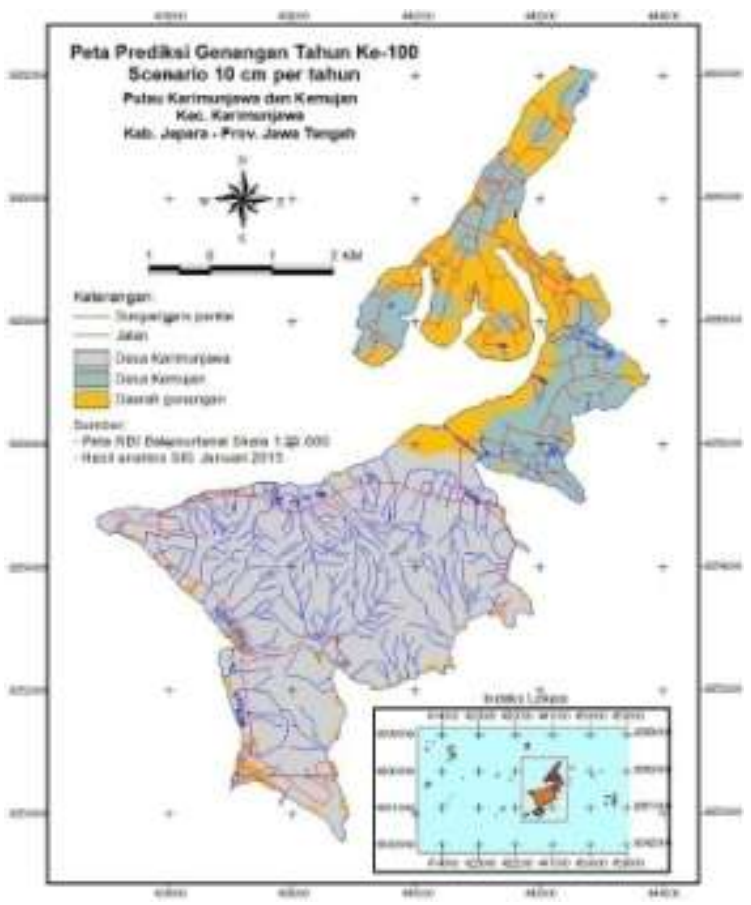

(d)

Gambar 6. Peta prediksi genangan air laut pada permukiman penduduk di Pulau Karimunjawa dan Kemujan, (a) prediksi genangan tahun ke-50 simulasi pada skenario kenaikan muka air laut $5 \mathrm{~cm}$ per tahun; (b) prediksi genangan tahun ke-100 simulasi pada skenario kenaikan muka air laut $5 \mathrm{~cm}$ per tahun; (c) prediksi genangan tahun ke-50 simulasi pada skenario kenaikan muka air laut $10 \mathrm{~cm}$ per tahun; (d) prediksi genangan tahun ke-100 simulasi pada skenario kenaikan muka air laut $10 \mathrm{~cm}$ per tahun;

Pada tahun ke-100 simulasi, dengan skenario kenaikan muka air laut $5 \mathrm{~cm}$ per tahun maka luas lahan untuk pemukiman akan berkurang sekitar 15,0\% dan dengan kenaikan muka air laut 10 $\mathrm{cm}$ per tahun, luas lahan pemukiman berkurang sekitar 40,0\%. Oleh karena itu dampak kenaikan muka air laut harus diperhitungkan dan diperhatikan untuk menentukan kebijakanyang akan dipilih untuk masa mendatang.

Kondisi kenaikan muka air laut yang berdampak terhadap pertumbuhan penduduk dan infrastruktur (pemukiman) di Pulau Karimunjawa dan Kemujan, membutuhkan adanya adaptasi sebagai upaya mitigasi dampak. Upaya mitigasi dapat dilakukan dengan pendekatan struktur dan non-struktur. Pendekatan struktur dengan membangun tanggul pelindung pantai, mengubah rancangan konstruksi bangunan permukiman serta perlindungan dan rehabilitasi ekosistem mangrove. Pendekatan non-struktur antara lain dengan merelokasi pemukiman penduduk ke dataran tinggi. Khusus untuk Pulau Karimunjawa dan Kemujan sebagai pulau kecil, sumber air tawar harus menjadi perhatian khusus. Teknologi pengolahan air laut menjadi air tawar sangat diperlukan untuk mitigasi dampak di masa mendatang. 


\section{Validasi Model}

Validasi model dilakukan pada subsistem pertumbuhan penduduk, karena subsistem ini mempunyai kelengkapan data times series sehingga memungkinkan untuk dilakukan validasi. Tujuan validasi model adalah memastikan kevalidan model dinamik/temporal yang dibangun (Gambar 3) dengan data referensi (jumlah penduduk).

Membandingkan perilaku grafik hasil simulasi dengan data referensi. Pada Gambar 7, perilaku yang ditunjukkan oleh hasil simulasi serupa dengan data referensi.

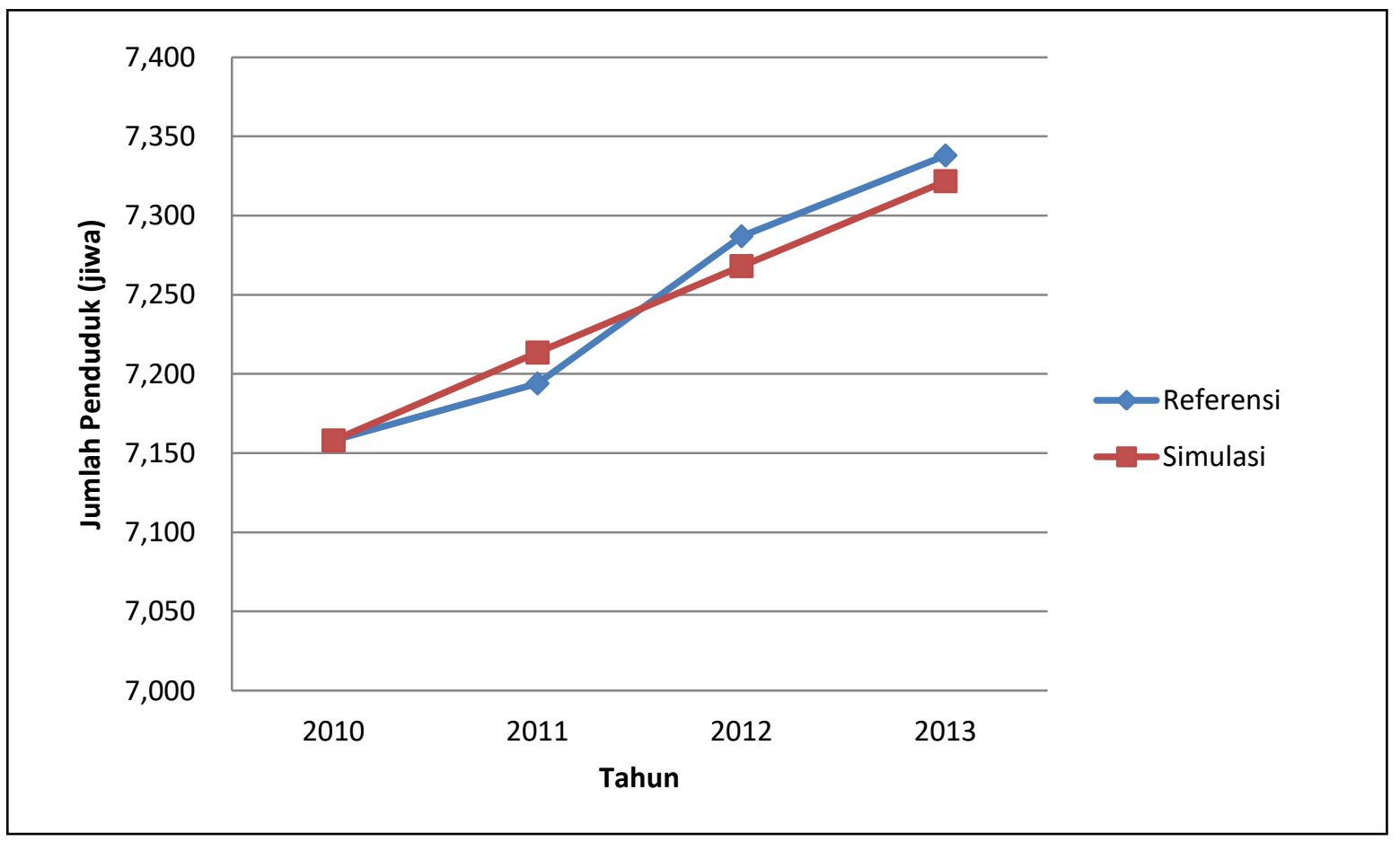

Gambar 7. Perbandingan pertumbuhan penduduk data referensi dan hasil simulasi model

Berdasarkan perhitungan, nilai AME validasi pertumbuhan penduduk sebesar: $0,054 \%$, sehingga dapat dikatakan bahwa model yang dibuat telah valid. Kriteria sebuah model dinamik/ temporal valid adalah jika nilai AME semakin mendekati $0 \%$, artinya tidak ada perbedaan signifikan antara hasil simulasi model dengan data referensi. Jika model dinamik/temporal valid, maka model tersebut dapat digunakan untuk menghitung dampak kenaikan muka air laut pada nilai tertentu.

\section{SIMPULAN}

Kenaikan muka air laut pada skenario model spasial dinamik/temporal pada $5 \mathrm{~cm}$ per tahun dan $10 \mathrm{~cm}$ per tahun akan memberikan dampak genangan yang sangat berbeda terhadap permukiman penduduk di Pulau Karimunjawa dan Kemujan. Pada tahun ke-100 diestimasi luas genangan 226,49 ha pada skenario kenaikan muka air laut $5 \mathrm{~cm}$ per tahun dan meningkat menjadi 618,15 ha pada skenario kenaikan muka air laut $10 \mathrm{~cm}$ per tahun. Perlu adanya upaya adaptasi dalam rangka mitigasi dampak kenaikan muka air laut terhadap penduduk dan infrastruktur (pemukiman) di Pulau Karimunjawa dan Kemujan sebagai pulau kecil yang mempunyai karakteristik berbeda dibandingkan dengan pulau besar. 


\section{REFERENSI}

Anonim. (2013). Laporan Akhir: Pemanfaatan Pemodelan Dinamika Spasial untuk Penyusunan Skenario Pengembangan Wilayah 7 Pulau Besar Berbasis Rencana Tata Ruang Pulau dalam Rangka Penyusunan RPJMN 2015-2019. Kerjasama Badan Informasi Geospasial dan PT. Gitamandalaksana Consultant.

BPS. (2016). Kabupaten Jepara dalam Angka 2016. Badan Pusat Statistik Kabupaten Jepara

Diposaptono, S., Budiman, \& Agung, F. (2009). Menyiasati Perubahan Iklim di Wilayah Pesisir dan Pulau-pulau Kecil. Edisi III. Bogor: Sains Press.

Dudley, R.G. (2008). A basis for understanding fishery management dynamics. System Dynamics Review 24 (1): 1-29.

Hafsaridewi, R., Sulistiono, Fahrudin, A., Sutrisno, D., \& Koeshendrajana, S. (2018). Resource management in the Karimunjawa Islands, Central Java of Indonesia, through DPSIR Approach. AES Bioflux 10 (1): 7-22.

Mimura, N., Nurse, L., McLean, R.F., Agard, J., Briguglio, L., Lefale, P., Payet, R., \& Sem, G. (2007). Small islands. Climate Change 2007: Impacts, Adaptation and Vulnerability. Contribution of Working Group II to the Fourth Assessment Report of the Intergovernmental Panel on Climate Change. Dalam Parry M.L., Canziani O.F., Palutikof J.P., van der Linden P.J., Hanson C.E (eds.). Cambridge: Cambridge University Press.

Muhammadi, Aminullah, E., \& Soesilo, B. (2001). Analisis Sistem Dinamis: Lingkungan Hidup, Sosial, dan Ekonomi Manajemen. Jakarta: UMJ Press.

Overseas Development Institute and Climate and Development Knowledge Network. (2014). The IPCC's Fifth Assessment Report. What's in it for Small Island Developing States?

Sahin, O. (2011). Dynamic assessment of coastal vulnerability and adaptation to sea level rise: an integrated spatial-temporal decision making approach. PhD Thesis. Griffith School of Engineering, Science, Environment, Engineering and Technology. Griffith University.

Sahin, O. \& Mohamed, S. (2010). Sea-level rise and adaptation response for coastal construction: A spatial - temporal decision making tool. 2nd International Conference on Construction in Developing Countries (ICCIDC-II). August 3-5,2010, Cairo, Eqypt.

UU No. 27 Tahun 2007 tentang Pengelolaan Wilayah Pesisir dan Pulau-Pulau Kecil. 


\section{INDEKS JURNAL MATEMATIKA, SAINS, \& TEKNOLOGI \\ TAHUN 2018}

agricultural extension, 25

air baku, 89, 90, 91, 93, 95, 96, 97, 98, 99, 100, 101, 102, 103, 104, 105

aquaculture stages, 126

banana, 1

blind source separation, 114, 115

bradyrhizobium sp., 80, 81

catfish, 37, 106

chicken manure, 72

communication barrier, 25

contribution of the Fisheries Sector, 57

destitute crackers, 106

distribusi non-gaussian, 115

divergen kullback-leibler, 115

diversity, 46

dumbo African catfish, 106

economy, 46, 57

ekonomi, 20, 35, 36, 44, 45, 46, 47, 48, 50, 54, 55, 56, 57, 58, 59, 65, 90, 107, 112, 139, 140, 142

eksplorasi, 81,82

environmentally friendly, 126

exploration, 80

Fish Protein Concentrate (KPI), 106

fishing, 46, 48, 53, 126

fuzzy binomial model, 8

fuzzy call optiom, 8

fuzzy volatility, 8

gambut pedalaman, $72,74,79$

glomus sp., 80, 81

GRDP, 57

guano, $72,74,75,76,77,78,79$

hambatan komunikasi, 25, 26, 27, 30, 31, 32, 33, 34, 35

human resources quality, 89

ikan koki baster, 127, 128, 131, 133, 134, 135, 136, 137

ikan lele dumbo afkir, 106, 107, 108, 109

ikan patin, 37, 38, 39, 40, 41, 42, 43, 44, 45

indigenous, 80, 81, 87

information theory, 114

infrastructure, 89

infrastruktur, 90, 95, 96, 97, 99, 101, 103, 104, 105, 140, 150, 151

inseptisols, 80, 81, 82, 84, 87

Jagung Manis (Zea mays L. saccharata Sturt.), 72, 74

Karimunjawa, 138, 139, 141, 142, 146, 147, 148, 150, 151 
keberlanjutan, 37, 38, 39, 40, 41, 42, 44, 45, 55, 137

Kemujan, 138, 139, 141, 142, 146, 147, 148, 150, 151

keragaan, 5, 6, 46, 47, 48, 49, 55, 56

kerupuk melarat, 106, 107, 108, 110, 111

Klassen Typology, 57

koki baster fish, 126

Konsentrat Protein Ikan (KPI), 107, 108

Kontribusi Sektor perikanan, 57

kullback-leibler divergence, 114

Kumpeh Ulu, 37, 38, 39, 42, 43, 44

Location Quotient (LQ), 57, 59, 63

management, 37, 126, 151

model, $8,9,10,11,17,20,21,23,24,41,42,55,89,90,91,95,105,114,138,139,141,142,143$, $144,145,146,150,151$

model binomial fuzzy, $9,10,11,17,20,23$

negentropi, 115,117

negentropy, 114

non-gaussian distributions, 114

opsi beli fuzzy, 9, 16, 18

outback peatland, 72

paclobutrazol, 1, 2, 3, 4, 5, 6, 7

PDRB, 57, 59, 60, 61, 62, 64, 66, 67, 68, 70, 71

pemisahan sumber buta, 115

penangkapan ikan, 46, 47, 48, 49, 52, 53, 54, 55, 56, 58, 134

pengelolaan, $37,42,43,44,45,50,53,55,56,95,96,97,99,101,102,103,105,127,136,137$, 139,141

penyuluh, 25, 26, 27, 29, 30, 31, 32, 33, 34, 35, 96, 97

petani padi, 25, 26, 27, 28, 29, 30, 31, 33, 35

pisang, $1,2,3,5,6,7$

planlet, 1, 2, 5, 6, 7

production improvement strategy, 126

pulau kecil, 44, 139, 140, 141, 146, 147, 150, 151

pupuk kotoran ayam, $72,74,75,76,77,78$

ramah lingkungan, 81, 127, 128, 136, 137

raw water, 89

rhizobium sp., 80, 81

rice farmer, 25

risk measure, 8

Sector Bases, 57

Sektor Basis, 57

Shift Share, 57

small island, 138, 139

socialization, 89

sosialisasi, 90, 95, 96, 97, 103, 104, 105

spasial, 139, 141, 143, 144, 145, 148, 151 
spatial, 138, 139, 152

strategi peningkatan produksi, 127

sumberdaya manusia, $26,27,58,90,96,97,99$

sustainability, 37,45

Sustainable Development Goals (SDGs), 106, 107

swallow guano, 72

Sweet Corn (Zea mays L. saccharata Sturt.), 72

tahapan-tahapan budidaya, 127, 129, 137

teori informasi, 114, 115, 116, 117, 118

Tipologi Klassen, 57, 59

triangular fuzzy curve representation, 8

ukuran risiko, 9, 11, 12, 13, 14, 16, 17, 19, 20, 21, 22, 23

volatilitas fuzzy, 9 


\section{INDEKS PENULIS JURNAL MATEMATIKA, SAINS, \& TEKNOLOGI TAHUN 2018}

Agung Prabowo, 8

Agus Susanto, 89

Asriani, 106

Ati Rahadiati, 138

Bambang Pramudya, 89

Benny Khairuddin, 138

Bulkis, 25

Eddy Supriyono, 37, 126

Erfen G Suwangto, 114

Ernik Yuliana, 37, 138

Etty Riani, 89

Hariyadi, 72, 74, 79

Hasan Eldin Adimu, 138

Hulaifi, 46, 47, 50, 56

Ignatius Danny Pattirajawane, 114

Joko Santoso, 106

Jotham S.R. Ninef, 138

Lina Warlina, 126

Lisnawati, 8

Luh Putu Ayu Savitri Citra Kusuma, 138

M. Yanuar Joko Purwanto, 89

Meitha M Kaihatu, 57

Muliani Galib, 138

Nurmala Pangaribuan, 80

Pramono Sidi, 8

Rani Hafsaridewi, 138

Robet Perangin Angin, 138

Sri Listyarini, 106

Sudirman Adibrata, 138

Susanti Mariam, 126

Susi Sulistiana, 1

Susilawati, 1

Yoyo Wiramiharja, 37

Zulfatul Mukarromah, 8 


\title{
INDEKS PENYUNTING JURNAL MATEMATIKA, SAINS, \& TEKNOLOGI TAHUN 2018
}

Untuk penerbitan Volume 19 Tahun 2018, semua naskah yang diserahkan kepada Jurnal Matematika, Sains, dan Teknologi (JMST) telah ditelaah oleh para pakar/mitra bestari/rekan setara berikut:

\author{
Lina Warlina (Universitas Terbuka) \\ Ludivica Endang Setijorini (Universitas Terbuka) \\ Dwi Astuti Aprijani (Universitas Terbuka) \\ Andriansyah (Batan) \\ Atun Ismarwati (Universitas Terbuka) \\ Benny Suprapto (Institut Teknologi Bandung) \\ Diki (Universitas Terbuka) \\ Eko Yuliastuti (Universitas Terbuka) \\ Etty Riani (Institut Pertanian Bogor) \\ Harmi Sugiarti (Universitas Terbuka) \\ Hurip Pratomo (Universitas Terbuka) \\ Jan Hotman (Universitas Terbuka) \\ Jarnuzi Gunlazuardi (Universitas Indonesia) \\ Mohamad Agus Setiadi (Institut Pertanian Bogor) \\ Nurmala Pangaribuan (Universitas Terbuka) \\ Sonny Suwasono (Universitas Jember) \\ Sri Listyarini (Universitas Terbuka) \\ Sudradjat Supian (Universitas Padjadjaran) \\ Susi Sulistiana (Universitas Terbuka) \\ Winarso Drajad Widodo (Institut Pertanian Bogor)
}

Ucapan terima kasih dan penghargaan setinggi-tingginya kepada para pakar/mitra bestari/rekan setara

tersebut atas bantuannya 